Van Devender, T R and Everitt, B L, 1977. The Latest Pleistocene and recent vegetation of the Bishop's Cap, south-central New Mexico: SW Naturalist, v 22, p 337-352.

Van Devender, T R, Freeman, C E and Worthington, R D, 1978, Full-glacial and recent vegetation of Livingston Hills, Presidio County, Texas: SW Naturalist, v 23, p 289-302.

Van Devender, T R and King, J E, 1971, Late Pleistocene vegetational records in western Arizona: Arizona Acad Sci Jour, v 6, p 240-244.

Van Devender, T R and Riskind, I) H, 1979, Late Pleistocene and early Holocene plant remains from Hueco Tanks State Historical Park, the development of a refugium: SW Naturalist, v 24, p 127-140.

Van Devender, T R and Spaulding, W G, 1979, Development of vegetation and climate in the southwestern United States: Science, v 204, p 701-710.

Van Devender, T R, Spaulding, W G and Phillips, A M, III, 1979, Late Pleistocene plant communities in the Guadalupe Mountains, Culbertson County, Texas, in Genoways, $\mathrm{H} \mathrm{H}$ and Baker, R J, eds, Biological investigations in the Guadalupe Mountains National Park, Texas: Washington, D C, Natl Park Serv Trans Proc ser no. 4, p 13-30.

Van Devender, T R and Toolin, L J, 1983, Late Quaternary vegetation of the San Andres Mountains, Sierra County, New Mexico, in Eidenbach, P L, ed, The prehistory of Rhodes Canyon, survey and mitigation: Human Systems Research, Inc, Tularosa, New Mexico, p 33-54.

Wells, P V, 1974, Postglacial origin of the present Chihuahuan Desert less than 11,500 years ago, in Wauer, R H and Riskind, D H, eds, Transactions of a symposium on the biological resources of the Chihuahuan Desert region, United States and Mexico: Washington, DC, Natl Park Serv Trans Proc ser no. 3, p 67-83.

1979, An equable glaciopluvial in the West, pleniglacial evidence for increased precipitation in a gradient from the Great Basin to the Sonoran and Chihuahuan Deserts: Quaternary Research, v 12, p 311-325.

1983. Paleobiogeography of montane islands in the Great Basin since the last glaciopluvial: Ecol Mono, v 53, p 341-382.

\title{
ERRATUM
}

\section{MOSCOW MV LOMONOSOV STATE UNIVERSITY RADIOCARBON DATES II SEA LEVEL INDICATORS FROM COASTAL USSR}

\author{
N I GLUSHANKOVA, O B PARUNIN, A O SELIVANOV, \\ A I SHLUKOV, and T A TIMASHKOVA \\ (Radiocarbon, Vol 25, No. 3, 1983, P 892-898)
}

An error in the geographic coordinates appears throughout the date list. All the data recorded as minutes should have been tenths of a degree. For example, the first date, MGU-IOAN-129 should read $78.6^{\circ} \mathrm{N}$ rather than as published, $78^{\circ} 6^{\prime} \mathrm{N}$. 